\title{
LEGAL REGULATIONS IMPACT ON SOCIAL CAPITAL. THE CASE OF POLAND
}

\author{
Lech Kurowski ${ }^{1}$, Piotr Szymaniec ${ }^{2}$
}

\begin{abstract}
The article's goal is to examine the impact of legal regulations on social capital on example of Poland. Due to specific conditions of Poland's history of the last 200 years, legal institutions were not supposed to contribute to creation of social capital and in fact made it difficult. Our objective is to investigate the role of positive law in social capital building process. In the authors' view, the relationship between statutory law and social capital is a complex one. On the one hand, a large stock of social capital supports statutory law, which can therefore be applied more effectively. Moreover, in such a situation, legal regulations do not have to be too detailed and casuistic. On the other hand, inadequate legal regulations may reduce the resource and quality of social capital, while well thought-out regulations can, in turn, support social capital. After review of literature referring to the relationship between the law and social capital, factors influencing social capital are discussed. It is followed by a short history of social capital evolution in Poland. After WWII, Polish legal system contributed to stressing the differences between identified groups, each of them enjoying different privileges. Due to bureaucratic character of this law, it did not help to strengthen social capital. Final section deals with general issues of the law-making process. We are presenting a tentative proposal to expand regulatory impact assessment (RIA) methodology, used in Poland and other OECD countries, by aspects important from social capital perspective. In our opinion, social capital building aspects were formally and practically forgotten during legislative process. Our suggestions on how to deal with social capital in the law-making processes are meant to propose corrective measures.
\end{abstract}

KEY WORDS: Social capital, Positive law, Poland, RIA.

\section{INTRODUCTION}

The article's goal is to examine the impact of legal regulations on social capital. Due to specific conditions of Poland's history of the last 200 years,

\footnotetext{
${ }^{1}$ Institute of Natural Sciences and Technology, Angelus Silesius University of Applied Sciences in Wałbrzych, Zamkowa St. 4, 58-300 Wałbrzych, Poland, e-mail: lkurowski@wp.pl, ORCID: 0000-0002-3667-3974.

2 Institute of Socio-Legal Studies, Angelus Silesius University of Applied Sciences in Wałbrzych, Zamkowa St. 4, 58-300 Wałbrzych, Poland, e-mail: pszymaniec@poczta.onet.pl, ORCID: 0000-0002-5415-9215.
} 
the state has been perceived by a large part of the society as an institution imposed from outside. Statutory law did not serve to strengthen social trust, but rather to achieve certain bureaucratic goals serving the government. During the "real socialism" period, even when specific social bonds based on mutual trust were developed, they were directed rather against what the state represented. Legal institutions were not supposed to contribute to creation of social capital and in fact made it difficult. During the transition period, it seemed relatively easy to make the appropriate legal changes. The sociologist Ralf Dahrendorf used the metaphor of "three clocks" in this regard. As he wrote, the lawyer's clock runs faster than the economist's clock, because constitutional changes can be introduced in a few months, while economic transition takes several years. Formation of a civil society (the third clock) may, however, take generations (Dahrendorf, 2017, p. $60)$. In this approach, legal changes determine changes in the mentality of members of society. Undoubtedly, legal changes trigger other changes, but in our opinion, the relationship between legal regulations and shaping attitudes and trust in society, being the basic element of social capital, are far more complicated. It seems that if the changes in mentality do not take place, the regulations intended to constitute a new legal environment for these changes will be applied in a distorted manner, and thus losing the intended effect. Our objective is to investigate the role of law in social capital building process, especially in the context of social and economic transition. We raise the hypothesis that the relationship between statutory law and social capital is mutual. On the one hand, a large stock of social capital supports statutory law, which can therefore be applied more effectively. Moreover, in such a situation, legal regulations do not have to be too detailed and casuistic. On the other hand, inadequate legal regulations may reduce the resource and quality of social capital. Well thought-out regulations can, in turn, support social capital by encouraging (nudging) people to cooperate and by influencing trust among members of society. The paper starts with detailed review of literature referring to the relationship between the law and social capital in order to identify gaps in the current approach to the issue. In order to substantiate the presented hypothesis we decided to use the example of Poland. Thus, after discussing the factors influencing social capital, we present a short history of social capital evolution in Poland. Next two sections of the paper deal with the impact of certain regulations (both those established in the period of Polish People's Republic, as well as the contemporary ones) on social capital of traditional and new communities. We follow standard methods of interpretation of legal provisions, developed 
on the ground of general theory of law, collected data about the application of certain regulations in the past or today, as well as achievable results of research carried out by sociologists and sociologists of law. Final section deals with general issues of the law-making process. After describing the place reserved for social capital in the assessment of draft regulations, we present our own proposal to expand regulatory impact assessment (RIA) methodology, used in Poland and other OECD countries. This element of the paper is of normative rather than descriptive character.

\section{OVERVIEW OF LITERATURE}

Most definitions of social capital emphasize that it consists of features of social structure (social organization), which enhance and improve human interrelations and cooperation in the society (Sztompka, 2007; Sztomka, 2016, pp. 282-315). Thus, social capital influences the society's efficiency of production (Putnam, Leonardi, Nanetti, 1993, p. 169). It is rather obvious that: "The existence of social and legal norms that foster certain behaviours is necessary for the generation of trust. Legal and formal institutions provide a framework for social behaviours to happen and be consolidated" (Zuleta Ferrari, 2016, p. 1147). Since social norms of any kind are essential in building trust and improving cooperation within a society, it appears that legal norms and institutions should be the core interest of scholars dealing with this issue.

However, it is not always the case. Many authors have focused on informal institutions (Levels, Scheepers, Huijts, Kraaykamp, 2015, pp. 766-779; Raiser, 2001, pp. 218-239). The subject addressed by scholars is the trust in legal institutions. Questionnaire researches are conducted to find out how effective a particular legal system is by members of this society.

Using term "effective", we mean one, considered by the prevailing opinion, in which individual's rights, and positive law duly protects liberties and the individuals have sufficient access to law enforcement institutions. Legal system is effective when the operation of legal institutions, in particular courts and judges, is perceived as impartial and non-discriminatory, and when its institutions are able to resolve vital problems of the citizens (Zuleta Ferrari, 2016, pp. 1154-1167; Zulera Ferrari, 2012, pp. 168-262). However, these investigations examine, in fact, only public opinion, and not the structure and operation of legal institutions themselves. Moreover, they assess legal systems and cultures at macro level and do not provide information concerning the impact the given legal institution has at the micro level. 
There are also attempts to assess the impact of legal change on social capital. One of the more recent contributions examines the influence of Code Napoléon on social capital in those parts of Germany where it was introduced. Johannes C. Buggle concludes that the introduction of Code Napoléon had a long-term positive impact on social capital, even though it was a top-down introduction and thus it caused discontinuity in the development of local legal institutions. As by Buggle, "the positive social consequences of the Code Civil manifest themselves in less political fraud in elections from 1871 to 1900, and in more "bridging" social capital in the 1920s" (Buggle, 2016, p. 148). The author is persuaded, that in the region with Code Napoléon in force over longer period (such as Palatinate, ceded to Bavaria in 1815 and Rhineland, which became later a parts of Prussia), higher level of interpersonal trust could be observed several decades after the Code was introduced. Such statements contradict views of scholars who, like Elinor Ostrom, claim that institutions, which enhance and maintain social capital, must be built in a bottom-up manner. We would not argue that breaking continuity of institutional development might have - although only under certain circumstances - a positive impact on social capital. As indicators of social capital in the $19^{\text {th }}$ century Germany, Buggle follows the data concerning membership in sport clubs (Turnvereine), the number of marksmen's clubs (Schützenvereine), as well as the per capita number of firemen- members of volunteer fire brigades. However, his methodology rises several questions. Even if, in the regions which adopted the French Civil Code, the number of some voluntary associations and the social participation in such associations was higher comparing to other German regions. Obviously, there was a correlation between two of them, however it would be difficult to prove the causal relation between them and it could be a result of other factors not traceable to Code Napoléon. Moreover, the Code did not regulate the activities of either sport and marksmen's clubs, or the fire brigades. The French Civil Code was treated here as a whole, however it regulated many aspects of social life such as marriage, paternal power and other family matters, use of property and performance of contracts. ${ }^{3}$ Some

${ }^{3}$ The Code Napoléon restricted the autonomous economic decisions of wives. Paragraph 215
stated that "The wife cannot plead in her own name, without the authority of her husband,
even though she should be a public trader, or non-communicant, or separate in property",
while paragraph 217 introduced further restrictions: "A wife, although non-communicant
or separate in property, cannot give, alienate, pledge, or acquire by free or chargeable title,
without the concurrence of her husband in the act, or his consent in writing" (French Civil
Code1). According to Code Napoléon, no women were allowed to be witness during official
activities and could not be legal guardians and participate in family councils, but this did not 
of the provisions of the Code might had a positive impact on social capital, while some others might had minor importance. Thus, it is difficult to adequately measure the impact of the whole Code on social capital. Perhaps, time-demanding archives searches could provide data on the number of court cases arisen on the application of particular legal institutions. They could shed more light on social impact of these institutions. We believe that study of the impact of legal provisions on social capital must focus on the very content of these provisions.

Examples from Polish legal system confirm that positive law itself is a factor that affects social capital. It could be a tool to improve bonding, bridging, and linking social capital as well. ${ }^{4}$ In particular, high degree of formalism introduced by legal regulations could impede building of social capital if they do not provide enough space for negotiating voluntary and informal arrangements between members of a given community.

\section{BUILDING THE SOCIAL CAPITAL}

Social capital, although difficult to measure, does have an impact on the country's population as a whole. When the majority shares common values, traditions and objectives, it is easier to resolve unavoidable conflicts between different social groups ${ }^{5}$. Overall development path is smoother without set-backs resulting from internal conflicts. Social capital also helps settle external shocks.

Given by its importance, the government should help with building (improving) social capital through promotion of different forms civil society organizations in which members take full responsibility for their actions. Closer links are being build, first between members of a group and then between different groups, be it choirs, sports clubs, reading circles etc. It would finally improve social inclusion of the widest country's population regardless their social, ethnic or cultural origin. As a result, society members behave with a self-restraint and develop respect for each other. Finally, it is reflected in risen

concern taking care for their own children and grandchildren.

${ }^{4}$ On bonding and bridging social capital, cf. (Putnam, 2000, p. 22). On linking social capital, cf. (Woolcock, 2001, pp. 11-17).

${ }^{5}$ R. Dahrendorf presents a very interesting perspective on conflict between social groups. According to him, Marx's classification, along the access to wealth and income criterion, does not explain the nature of contemporary post-industrial conflict. Industrial workers class reduced in number and the workers were free to join the capitalist class through acquisition of stocks. Analysis of present conflicts should consider social groups identified by the criterion of access to authority. (Dahrendorf, 1959; Tittenbrun, 2013). 
productivity of the society, quality of its services and innovative initiatives due to synergy effects and faster direct information flows.

No central authority may succeed in in building the civil society in a topdown manner. Authoritarian decisions make winners and losers and lead to conflicts. Governments could only create fertile ground for the society to flourish, without telling directly people what to do, how and when to do it (Friedman, 1982, pp. 22-36). A civil society empowered adequately is a precondition for existence and accumulation of social capital.

Social capital is intangible; nevertheless, many scholars as well as politicians (Knack, 2003, pp. 42-84) recognize its role and contribution to GDP since any exact measure of it appears impossible. This is probably the reason why economists devote rather no attention to it comparing to accumulation of capital invested in production, infrastructure or human resources. Nevertheless, social capital and whatever fitting into its scope prove positive economic benefits. In the short run, it helps to sort out small conflicts and deal with unexpected events. United and disciplined society with population consciously accepting their role eases achieving the long-term goals set by the government and agreed in a democratic way by the stakeholders. Existence of social capital, reflected in acceptance and respect of rules and legal regulations, reduces economic and social costs of governance. Every regulation, which prohibits certain activities, orders or relaxes constraints on certain activities, has an impact on human relations. Consequently, it strengthens or deteriorates the "stock" of social capital to some extent.

Due to the nature of social capital, it is difficult to devise specific programs to address its improvement. Apparently, the best what the legislators and the government could do is to involve the necessity of social capital to their decision-making processes. Therefore, a third dimension needs to beincluded to economic and distributional considerations. It would be in line with the ongoing discussions on shortcomings of measures of economic performance used globally. ${ }^{6}$ This paper is not intended to suggest its implementation in practice, however, government decisions modifying income distribution in the name of social justice do not necessarily contribute to building the social capital.

\footnotetext{
${ }^{6} \mathrm{GDP}$, as a synthetic measure of economic performance, was considered as insufficient even in the 1990s, when UNDP introduced Human Development Index. This composed of GNP and additional elements, which take into account distribution of income and the quality of life. Today, the Gross National Happiness Index proposed in Bhutan in 1972, is not considered "exotic" any more due to some of its merits. Cf. (Tideman, 2016, pp. 190-213; Tideman, 2011, pp. 133-153).
} 
Government's role would be to devise policies and create conditions to improve cooperation and understanding between different overlapping interest groups. Such policies would stimulate social initiatives to tap unused resources and improve social wellbeing.

\section{SOCIAL CAPITAL AND POLISH HISTORY}

Various strong shocks the country went through the last hundred years caused Poland's failure in creating a favourable ground for building the social capital. Each of the shocks influenced social capital.

The first of them was creation of national statehood in 1918, after over 120 years of partitions. The new state - Republic of Poland was comprised by three geographical parts ruled until then by three different political cultures of Russia, Austria and Prussia (Germany), and at least by four different legal systems ${ }^{7}$ Economic inequalities in the new state were immense. Agriculture was the basis of livelihood for $62 \%$ of the population. Industry was developed only in the southwestern and central parts of the country (Ajnenkiel, 1962, p. 30). ${ }^{8}$ Revived Poland was composed of several nationalities. Based on population census in 1931, the entire population count was 31.7 million (by 1935 an increase to 35 million) with 14 percent of Ukrainian and "Ruthenian" ethnicity. Jews represented the second minority with $8 \%$, other minorities were Belarussians (3\%) and Germans (2\%) (Koryś, 2018, pp. 207-253). Each group had its traditions, religions ${ }^{9}$ and languages - the strongest links, beyond family, keeping people together.

\footnotetext{
${ }^{7}$ In the part of the Kingdom of Poland (or Congress Poland), private law, modelled after Napoleonic Code, was introduced in the period of Duchy of Warsaw (1807). Thus, the amalgamate of French, Russian and local laws was in force (the latter were introduced in the period of semi-independence of the Kingdom of Poland, 1815-1830). The Eastern and Northeastern parts of newly born state (with Wilno as the major city) were previously incorporated to Russian Empire, so tsarist law was in force. In the Western and Northern part of Poland, Prussian and German law (including Bürgerliches Gesetzbuch of 1896) was in force, while co-called Galicia was governed by Austrian law (moreover, Hungarian law was binding in Spisz and Orawa regions, but it was quickly replaced by Austrian law). Criminal law was unified as late as in 1932, while the task of unifying civil and family law was never completed in the interwar period.

${ }^{8} \mathrm{Cf}$. the new synthetic work on the issue: (Koryś, 2018, pp. 207-253).

${ }^{9}$ In 1931, the percentage of non-Roman Catholic inhabitants was 33.7. $10 \%$ of inhabitants declared themselves as being of Jewish denomination (Koryś, 2018, p. 224). The difference of the number of people declaring themselves as being of Jewish ethnicity and of Jewish religion follows of the fact that significant, but not very large part of Jewish population was assimilated. The work of Anna Landau-Czajka offers an in-depth analysis of the process of assimilation, underlying also its limitations. (Landau-Czajka, 2006).
} 
While some ethnic and social groups were quite indifferent, if not hostile to the new Polish statehood (just to mention Ukrainians and Germans), development of national social capital was next to impossible. It was only twenty years to the WWII - time insufficient for the country to make a visible progress in this area considering the fact that it run into serious problems arising from conflicts and cultural differences.

War times and occupation (1939-1945) prepared some common ground for cooperation and social unification built on resistance against the occupants (Karski, 2013). However, political differences and past ethnic animosities persisted, at least to certain extent. Some of them even deepened after the war. ${ }^{10}$ Liberation of Poland from German occupation by the Soviet troops brought a new regime and a new political system, both claimed to be the one of social justice (Kersten, 1991, pp. 163-231). The communists, a political minority in the pre- war times, came to power secured by both the Polish army and newly installed Soviet bases. ${ }^{11}$ Any signs of popular resistance were crushed by force, especially during the first post- war decade. The population had accepted reluctantly new rule. Central planning, a part of the soviet style government, did not create any incentives for citizens' initiatives. No place was left for them. Strict implementation of top-down directives in practise was remunerated. New ruling class did not trust the population at all, so the system was built on using any possibly to control all aspects of the life. Bottom-up initiatives, if not controlled or guided, were identified as eventual threats to the system. The governmentcontrolled propaganda played an important role in this system. On several occasions, the ruling group (dominant party and the government) attempted to propose issues directed to (mis)lead and concentrate the public opinion against a selected scape-goat, usually a distinctive group called "people's enemy" (Eisler, 2005, p. 160, 172; Trembicka, 2014, pp. 105-120). The enemy would be blamed for government's failure in securing basic necessities. Such measures might had helped the government out of immediate trouble, but in fact, they only deepened social divisions and definitely contradicted to social capital building. Less frequent, propaganda actions addressed some positive themes referring to thoroughly selected patriotic traditions. ${ }^{12}$ They had, however, enemies in the background and

\footnotetext{
${ }^{10}$ Just to mention the Kielce pogrom which took place in July 1946 and met with kind of acquiescence by communist secret service (Prażmowska, 2002, pp. 101-124).

${ }^{11}$ The last Soviet troops left Poland as late as in September 1993.

${ }^{12}$ Since the 1960s, the authorities increasingly used the nationalistic discourse (Zaremba, 2005).
} 
were in reality of nationalistic nature. As a paradox, growing dissatisfaction with the country's economic performance led to improvement of the social capital in the 1980s. (Koralewicz, Białecki, Watson, 1987; Tracz, 2015, pp. 37-53). The government, retaining her power only thanks to military support, was finally forced to admit her failure and agreed to share the power with representatives of the majority, demanding the changes.

Transition to a new system, which followed, was expected to be painful, but short (Sachs, 1994). ${ }^{13}$ In the name of national solidarity and thanks to accumulated social capital, population was ready to suffer short-term economic hardships with the promise of a better future. Transition from central planning to market economy brought price adjustments. Government -controlled price system was replaced by market mechanism. Scarcity of products and black market, always existing when prices are controlled, turned into 2-3 digits inflation once prices were liberalized. Simultaneous privatization gave opportunities to more entrepreneurial individuals to acquire sizable parts of the former state-owned property, while the majority of working population was actually losing their purchasing power. What was expected to be a short shock, lasted over 10 years (Khan, Alam, Anós Casero, 2008). ${ }^{14}$

Market economy brought about inequalities and a competition not only between business entities, but also between workers looking for scarce jobs. Harsh competition did not help human interrelations and depreciated the stock of social capital accumulated in the 80s. The former full-time job scheme was replaced with short-term jobs and occasional contracts without paying out any leave entitlements and other benefits, as was with the full-time employment. This transition and Poland's full membership in the EU (in 2004) has brought economic stability and continuous growth at the rate slightly exceeding European averages. Opening of the EU borders helped to solve unemployment issues. On one side, around 2 million Poles have found their permanent or temporary (usually low-skilled jobs) in the EU countries. ${ }^{15}$ Inflow of foreign capital was the other effect. Seen from

\footnotetext{
${ }^{13}$ For critical analysis of transitive economic policies, cf. (Łaski, Bhaduri, 1997, pp. 103-121; Kowalik, 2011, pp. 105-170; Ost, 2005, pp. 55-65).

${ }^{14}$ In fact, it was reported here that the transition in Eastern Europe, which had started at the beginning of the 1990s, was over, however not all the concerned would agree.

${ }^{15}$ According to the census of 2002, 786,1 thousand Poles were staying temporarily abroad. The Statistics Poland Office (Główny Urząd Statystyczny) reported that at the end of 2007, 2 million 270 thousand Poles temporarily stayed abroad, out of this number 1 million 860 thousand were staying in the EU Member States. In addition, the vast majority of people included in this number stayed abroad for more than 12 months (this feature distinguishes
} 
the short- and medium-term perspective, the consequences were positive. However, from the social- capital aspect, their longer-term impact proves some threats now. Polish migrants are mostly younger people, often welleducated and aware of how to search for better opportunities abroad. ${ }^{16}$ They are willing to accept jobs under their qualifications to get a well-paid job. This represents a loss for their home country, which payed for their education. Today, Poland already faces demographic crisis with low birthrates and growing numbers of the retired. ${ }^{17}$ Emigration of young people only aggravates the future of pension system and increases inequality of income distribution. Unavoidable government intervention in such situation would not help in building social capital. Increase of taxes aimed at providing more benefits to a specific group, usually is done at the cost of other groups of people. Inevitably, it leads to rifts among those who pay and the beneficiaries.

Government, for political reasons (in order to get more popular support', might also use other measures to generate distrust and/or undermine established moral or professional authority (such as in Poland medical or legal profession). Recent history of Poland illustrates that all such populist solutions polarize the society and have negative effects for social capital in the longer perspective. Building social capital takes a long time, destroying it just might take months.

\section{LEGAL REGULATION AND SOCIAL CAPITAL OF TRADITIONAL COMMUNITIES}

Studying common pool resources in Poland in the context of Elinor Ostrom's studies, made us to conclude that working out a sustainable use of resources (products) by all the stakeholders takes a stretch of time. Moreover, we noticed that the oldest informal village organizations on Polish lands (grazing on common pastures, using community-owned forests or jointly organized flood protection) operated without outside regulations.

migration after Poland's accession to the EU from pre-2004 migration). (Kaczmarczyk, 2008, pp. 17, 28-30).

${ }^{16}$ Research from 2005-2007 showed that persons aged 25-29 accounted for over 30\% of emigrants. The share of people with higher education in this group was $30 \%$ (Kaczmarczyk, 2008, p. 36).

${ }^{17}$ According to the official sources, level of total fertility rate (TFR) has been below $2 \%$ since 1990 , and in 2017 this rate was $1.45 \%$ o (both figures are below the UN declared ReplacementLevel-Fertility of $2.1 \%$ ). In 2017, the number of retirees per 100 working age population count was 34, while in 1990 this number was only 22. Moreover, in 2017 population under legal working age was 29 people per 100 working age population, proving a significant decrease (by 23) compared to 1990 (Główny Urząd Statystyczny, 2018, pp. 29-30, 43). 
Each member saw not only individual interest in getting some benefits and was also expected to maintain the limited resources at the village had at its disposal. It required understanding of the others as well as respect of community-imposed limits on consumption. Such arrangements worked out in sedentary populations over generations.

Economic development and state- introduced legal regulations have caused changes to the operation of the system. Former stakeholders had to conform to new regulations, which were often disruptive to the equilibrium of the past. Old, mutual understanding between the members replaced the rule of law. Market mechanisms introduced competition with all its positive and negative aspects of cooperation including growing inequality, where some had bigger claims to common property than the others do.

The communities built on trust and understanding are governed by the rule of law now. Regulations of the long-established communities meant to introduce a uniform approach across the country ${ }^{18}$ had two consequences. On the positive side, uniform rule of law was introduced throughout the country's territory. It had, however, negative impact on the traditional selfregulated local communities, where locally agreed by-laws ceased to be operationally binding. Consequently, the regulations had negative impact on social capital built up locally over generations. They interfered with the spirit of cooperation between community members and their involvement in managing common affairs for the members' long-term benefit, including protection of the jointly used property.

In case of common pastures and common forests, the remnants of old institutions have preserved. They are located mainly in the past tsar-ruled parts of Poland, with no significant migration flows after the World War II. Easements (serwituty) for the local rural community were confirmed by tsarist administration in the course of the $19^{\text {th }}$ century and they stayed still valid after Poland gained the independence in 1918. However, the communist regime introduced Act of June 29, 1963 on the management of common lands (Polish Journal of Laws [PJL], No. 28, item 169), and it replaced the easements with obligatory partnerships. Therefore, much more formalistic approach to using these common areas was implemented, compatible with the entire scheme of planned economy. This departure from the traditional way of managing these areas based on by-laws and cooperation. Today, the land communities are still a common phenomenon. According to Piotr Gołos, in 2008 such communities existed in as many as

${ }^{18}$ Over the last century, Poland's borders were subject of two important modifications: in 1918-1920 and in 1945. 
447 local communes (gminy) (Gołos, 2008, pp. 54-68). Moreover, common sheep grazing areas, regulated by the customary law, still exist in the Tatra Mountains. However, they are virtually without any economic importance. In the period of the Polish People's Republic, the authorities tried hard to break traditional highlander communities, so when Tatra National Park was created in 1954, the possibility of common sheep grazing was curtailed. In the 1960s and 1970s, this led to the sharp conflicts between the authorities and the Park's administration on the one side and local communities on the other, (Korzycka, 2018, pp. 185-187, 190-192). Certainly, such conflicts reduced the stock of social capital in the local communities.

The Water company is another example of a traditional institution, which had managed such common pool resources as water intakes, flood protection and irrigation devices. It was introduced to Polish law just after World War I, in 1922 ("Water Act" of September 19, 1922, PJL, No. 102, item 936). However, Wassergenosenschaften were present in the parts of Poland incorporated into Prussia and Habsburg Monarchy. It was decided to regulate water companies in a very detailed way. Only little space was left for the ideas of individual community members on how to regulate the usage of their resource. As in the related sources, the structures and installations built and managed by water companies were not of high quality (Nowakowski, 2006, pp. 456-457; Dawidowicz, 1959, pp. 90-103). The 1922 Water Act regulated also the levee unions, i.e. companies dealing with the construction and maintenance of flood protection embankments. The regulation of water companies remained in force in the post-war period. However, during the Stalinist era only few institutions existed formally with no decisionmaking power. Later on, water companies still existed but administrative supervision over them strengthened and they were included to the planned economy. ${ }^{19}$ Both legal act of 1962 as well as the one of 1974 provided that a water company was created by administrative decision, without approval of their members (Article 112 of the "Water Law": of May 30, 1962, PJL, No. 34, para 158; and Article 110 of the "Water Law" of October 24, 1974, PJL, No. 38, para 230). Moreover, the internal organization of a company was also strictly state- law regulated. After 1989, the legal character of water companies slightly changed. However, the "Water Law" of July 18, 2001 (PJL No. 115, para 1229) did not foresee the institution of compulsory water company. The current "Water Law" of July 20, 2017 (PJL, item 1566), treats a water company as a non-profit organization, however it maintains

19 They were considered as the "units of socialized economy" (jednostki gospodarki uspołecznionej). 
its highly formalized internal structure. Among others it specifies types of internal bodies, their composition and procedures, like management, annual members assembly and in case of larger companies (more than ten members) also an audit commission. According to Elinor Ostrom (Ostrom, 1990), "bottom-up" ways of common pool resources management can be both economically efficient and conducive to the creation and maintenance of social capital. Polish pre-war legal arrangement of water companies and levee unions was at least eventual tool for strengthening social capital in rural areas, although the matter could be seen as overregulated. Water companies operating under strict rules are not always efficient. Due to bureaucratic character, the post-war regulations of water companies lost their meaning as useful instrument for maintaining the stock of social capital.

\section{LEGAL REGULATION AND SOCIAL CAPITAL OF NEW COMMUNITIES}

Polish regulations provide for two models of property in common use for housing communities: one for small communities composed of up to three apartments, ${ }^{20}$ and the other for larger communities (Article 19 of the Act of 24 June 1994 on Ownership of Apartments). Small communities manage property in common use in accordance with the provisions of the Civil Code and the Code of Civil Procedure regarding the joint ownership. It is important that a larger community cannot opt for the model designed for small communities (Strzelczyk, Turlej, 2015, p. 489).

In case of small communities, all decisions concerning issues exceeding ordinary management of a common property require consent of all coowners. Moreover, if there is no such an agreement, the co-owners who, dispose of at least half of the shares in the commonly- used property in total, may request a court decision (Article 199 of the Civil Code). At the same time, the regulations impose on the co-owners obligation to cooperate in the common property management (Article 200 of the Civil Code). However, decisions regarding current property management are made with approval of the members representing the majority of shares. The regulations protect the owners against the decisions violating the principles of good management of real estate. In case of such a decision, each of the disagreeing co-owners may request the court decision (Article 202 of the Civil Code). At the same time, other methods of conflict resolution are not excluded to avoid the court's intervention, e.g. mediation is possible. In case of small

${ }^{20}$ Until 2019, small communities were considered housing communities up to seven apartments . 
communities, management, decisions on commonly used property requires participation of all owners. An administrator might be appointed only if no majority agreement is possible on important management issues, and "if the majority of co-owners violates the principles of proper management or harms the minority" (Article 203 of the Civil Code). In such situations, each of the co-owners is entitled to bring the case to court attention in order to appoint an administrator. The members agree on the rules and ways of common property use. These rules are also binding for new members of the community (Article 221 of the Civil Code).

Management of larger communities is more formalized than that of the "small" ones. Legal regulations visibly favour bureaucratic style of housing communities' management. Consequently, they strengthen the position of a professional manager. Questionnaire- based research made on housing communities indicates week involvement of their members in a day-today management. Several members claimed they would take care of the community themselves. However, high rate of members considered the current professional management be over their expectations. The study clearly confirmed selfish attitudes of some members, who do not care so much about the community, but about their own apartment (some of the respondents say e.g.: "Why should I pay for a repair if my apartment does not run into water?") (Szczepańska, 2014, pp. 197-216). Attitudes towards jointly used property in this case testify to the deficit of social capital. Better-developed social capital would not need formalized legal regulations. Simultaneously, regulations of this nature intended to substitute selfmanagement do not contribute to building the communities based on trust and mutual cooperation of their members.

Legal regulation of both traditional (e.g. water companies) and new communities leaves little space for members' initiatives to run their common affaires. On the one hand, it is inherited from the planned economy, when such communities were subordinated to bureaucratic rules imposed by the state. On the other hand, formal regulation has been maintained until today. A significant part of society still expects the state to define the legal framework precisely for the communities sharing benefits from common resources. We believe, this expectation proves deficit of social capital, and existing mistrust among people. Moreover, a more general comment at this point should be made. It seems there is a trade-off between formal detailed legal regulation and by-laws adopted at the community level. At present, statutory law does not promote social capital, which in turn could produce by-laws adapted to specific conditions and needs of individual communities. 


\section{LAW-MAKING AND SOCIAL CAPITAL}

Considering the society as a structure built up out of bricks, then social capital can be presented as binding material keeping the structure together. The structure is composed of individuals organized in separate groups, each having own objectives, often in conflict with each other. Social capital is the bridging link between those groups. Currently the highest level of organization is the state within its borders. The government elected in democratic vote sets its objectives. In order to achieve these objectives, the cooperation and cohesion of all the components are needed. Sometimes conflicting interests of individual groups need to be regulated by law. Natural tendency to maximize benefits of the group have to be mitigated in order to bring them in line with the state's objectives set by the government, which represents the majority. It follows one of the economic rules, saying that what is good for an individual (at the microscale) is not necessarily good at the macro scale. The macrostructure is efficient when there is no internal conflict. The Existing social capital, a binding material in this case, keeps the structure together. Legal regulations might strengthen this structure or contribute to its erosion.

Social capital is built mutual understanding between members of the society. It is obvious that it is easier to reach consensus among small groups. The government has a role to play in creating the social capital within the country, which should bring final positive outcome to the GDP. The task is more complicated at the macro level because the government, after the election process is completed, in fact, represents just parties in power. Consequently, it becomes the representative of the majority of voters voting (usually $50-60 \%$ of the eligible voters). In the democratic system, logically, those, who brought the government into power, are privileged against the opposition. However, behaviour of the party in power usually changes over time. On the one hand, it would need to remunerate the faithful supporters; on the other hand, it cannot completely neglect the opposition. The policy would have to be modified in view of the upcoming elections. As the level of popular support changes over the time, it is only natural that not every supporter is satisfied with the government policies. Before elections, the party in power should make it sure about the traditional support and try to attract new supporters. Competition between the parties for support does not help in building understanding among the people. All over the world, political parties concentrate rather on seeking differences then on positive issues. Political campaigns are getting nasty very often. The 
opponents are blamed not for their public deeds, but rather on, often exaggerated, inglorious episodes from their private life and/or life of their family members. Such pre-election party campaigning does not help to build national understanding and it might have long- lasting consequences for social capital.

Law-making is an expression of the government policy. Every new law passed by the Parliament has a certain impact on human relations. The impact could be direct or indirect, smaller or bigger.

From the social capital aspect, legal regulations are generally classified into two categories: laws giving moral satisfaction; and laws changing distribution of income between social groups. The first category of laws, although it might be rather controversial sometimes, does not involve considerable budget expenditure in most cases. Some of the laws in this category, however, are ideologically-based. Their adoption might threaten delicate distribution of power within the country. In Poland, for instance, the relaxation of the anti-abortion law and the awaited new regulation on financing the religion classes in public schools - topics present and important in public discussions - are postponed now not to antagonize the Catholic Church. The politicians use pending issues, like the ones mentioned above, and it seems that this is not in order to solve the problem but rather to anger and/or provoke the opponents to take a stand on the issue. "Poke a bear" policy contributes to social polarization and often creates conflicts even within families.

Law-making, which deals with ideological issues, in some cases concerns also international relations. Poland, as member of international organizations, has to harmonise its legislation with commitments made by previous governments. Nationalistic policy, which might be useful for solving short-term internal problems and getting wide support, often includes elements offensive to other nations. As such, it is harmful for building longterm friendly relations with individuals from other EU countries. Nationalism constitutes potential economic threat to the economy. Low rate of population growth requires inflow of immigrants. Hostile attitudes towards foreigners might be an obstacle to this process. From this perspective, the country needs a policy of inclusion and integration of immigrants into Polish society without pushing them into cultural or ethnic ghettos, sources of potential problems.

Income stratification of the population is another problem to be addressed by the government. Growing income gaps observed all over the 
world ${ }^{21}$ contribute to social problems. Different policies could be followed in this area. Basically, they can be classified into two categories.

The first one, short term solutions, those of the "Bolshevik type", consist of increasing transfers to the poor at the cost of those who are better off. The determination of poverty, of its absolute and relative levels, is the subject in itself. Redistribution of income by taking it away from the "rich" to give it to the "poor" is a populist short term operation usually aimed at getting wide support as there are more voting poor than voting rich. In spite of the fact that this short-term populist solution brings immediate results, it has potentially longer-term consequences. It cannot be a one-time operation only, so it increases future fixed budget commitments, while future budget revenues fluctuate with the GDP. The windfall money is happily accepted by its beneficiaries but discourages them from making efforts to search better opportunities on their own. It might even spin the vicious circle of poverty within families. Some experts consider an increase of subsidies as psychological obstacle to getting out of poverty ${ }^{22}$. Although direct payments to poor people immediately improve their material status, they do not contribute to better understanding between social groups. Increased taxes create dissatisfaction and deepen rift between social groups - beneficiaries and contributors. The funds spent on subsidies would bring probably similar results if used for alternative projects. However, the results would be visible only in longer term. This confirms that the subsidies were used for political reasons ${ }^{23}$.

\footnotetext{
${ }^{21}$ The end of the "cold war" in 1990s generated hopes and expectations that unnecessary military spending by the competing blocks could and would be used to fight the world poverty. Elimination of poverty and reduction of inequality became the topic of numerous publications and internationally supported programs, among others UN Millennium Declaration. Thomas Picketty, in depth statistical study of the last 200 years of world development came to a conclusion that inequality in the capitalist system would grow, unless there are government (or international) undertake measures to stop this process (Picketty 2014). Joseph E. Stiglitz extensively discusses negative impacts of inequality on all the aspect of human life. He writes about inequality reducing trust and cooperation among people - essential elements of social capital, which "is the glue that holds societies together" (Stiglitz, 2012, p.122).

${ }^{22}$ For the classical version of the argument, cf. (Mead, 1986, pp. 120-147).

${ }^{23}$ Declared objective of the Polish " $500+$ program", focused on paying 500 zlotys month subsidy to the families with two or more children for each second and next child, was to increase the low birth-rate. The subsidies were to be payed until the children were 18 years old, were supposed to encourage families in having more children. Very soon, when it was clear that the birth-rate did not grow sufficiently to justify the program, the government announced its success in "reducing poverty". Was the original objective still valid, the program would be a failure. Its cost is close to $5 \%$ of the state budget and is financed through various tax increases (direct and indirect). It also has its role in the higher inflation, which,
} 
Social equity is not achievable through distribution of money to the needy. Such a policy makes winners and losers and drives a wedge between them. Personal merits of individuals should acknowledge their material status. However, material equity cannot be the objective in itself. We believe that government's objective in this area should be to guarantee equal opportunities for all the children and young people aged 18-20. In practical terms, it boils down to general provision of good basic education, healthcare and satisfaction of basic needs. All of that would allow young people to understand their individual intellectual capacities as well as limitations and mature selection of a future line of their professional career (Sen, 2009, pp. 12-14, 291-317, 396-398).

Policy and legal regulations oriented towards equal opportunities offer several advantages compared to the "Bolshevik type" policies. In terms of social capital, in the short run they do not contribute to negative sentiments among social groups. In longer perspective, it is easier for all to accept public spending on open access programs (such as education or public healthcare improvement), but benefiting in particular less privileged. A good guideline principle for the lawmakers would be to avoid taking such decisions that make clear winners and losers, such as taxation of some (usually better-off) to finance subsidies benefiting selected groups of the society. Similar result, however in longer term, would be obtained if the benefits distribution pattern, including both incomes and free public services, was determined on incremental basis. Dealing with incremental product following the "Pareto Optimum" allows to improve the situation of those in need without making the others worse. Consequently, it would not be a source of a potential conflict detrimental to social capital.

The legislation process in Poland follows the regulatory impact assessment (RIA) methodology adopted in 2001 (partly changed in 2006). This methodology is based on OECD proposals from mid-1990s. (Zubek, 2007). According to its assumptions, the preparation of RIA includes description of the problem to be regulated, purpose of regulation, possible approach to achieve the identified objective (by regulation or by alternative solutions), estimation of significant effects for consumers, businesses and other interest groups (Śliwa, Żaba-Nieroda, 2017, p. 371). The central

to some extent already reduced purchasing power in 500 zlotys. The program produced also negative consequences for labour market. A sizeable number of young women gave up their jobs because low income entitles them to claim 500zl for their first child as well. According to cautious estimates, the program caused around 40.000 mothers caring for their children failing out of from the labour market. Cf. (Ruzik-Sierdzińska, 2018, pp. 63-75; Magda, Kiełczewska, Brandt, 2018, pp. 4-18). 
point of the methodology is the questionnaire approved by the Council of Ministers. It consists of thirteen fields and contains four basic elements: 1) identification of entities (groups of stakeholders) on which the regulation will have an effect; 2) assessment of the impact of regulation on public finance; 3 ) assessment of the impact on economy's competitiveness and entrepreneurship, families, citizens and households; and 4) indication of the regulation's impact on such areas as natural environment, regional development, demography, health care, "informatization", ${ }^{4}$ and state property (Rogowski, Szpringer, 2007, p. 8). Subsequently, consultations with stakeholders should take place and recommended solutions be proposed.

It is worth noting that the categories used in Polish RIA's methodology are very heterogeneous and even and in some points incoherent. Under one heading such different areas as environment, development and state property are included. As a result, the assessments made are often sketchy. The questionnaire requires very general answers the "yes/no" questions without any attempt to indicate the strength of the impact. Although the questionnaire allows identifying other impacts, this field is rarely used, probably because it would require written explanation "why". In practical application bureaucrats in a way to serve other bureaucrats use a wellintended approach RIA. Thus, in practice, the most important element of RIA is the assessment of impact of the regulation on the state budget and public financial sector in the 10 -year perspective counted from the date of the regulation adoption. Current RIA methodology identifies stakeholder's circle. Assessment of regulation's impact on social capital should deal with wider dimension. It should include the impact of a draft regulation on the entire society including its key components.

At present, respective ministry introduces a questionnaire - based law proposal. According to its authors, although it is supposed to collect comprehensive information on the new law proposal, it has become a bureaucratic tool considered often as a nuisance by its users. Probably a checklist of topics dealt with by the legislation proposal would be a better tool for the comprehensive analysis of a draft. While the questionnaire requires answers to all the points listed, the checklist would offer a menu to choose from only the relevant items.

The table below is a tentative proposal to expand RIA methodology by aspects important from social capital perspective. We have identified the main areas of regulation having influence on trust and understanding among citizens at group and inter-group level. We fully understand that the effects

${ }^{24}$ Understood as contribution to building the smart society. 
of specific regulations might have different impact in short and long term. However, in case of inter-human relations, the legislator should be patient as the effects and regulation's consequences might appear in much longer perspective. ${ }^{25}$

Table 1: Scale of impact

\begin{tabular}{|c|c|}
\hline AA & Strong positive impact (prime objective) \\
\hline A & Positive impact (secondary to prime objective) \\
\hline BB & Neutral in the short run \\
\hline B & $\begin{array}{c}\text { Future consequences (positive or negative) depend on complementary } \\
\text { regulations yet to be introduced }\end{array}$ \\
\hline CC & Conflict generating potential in short run \\
\hline C & Likely future threats (inter-generational distribution of income) \\
\hline
\end{tabular}

Source: Authors

Table 1 introduces the proposed assessment scale of regulation's impact on social capital. It follows to some extent the scale adopted by the agencies rating perspectives of countries and large companies. A tool to assess the impact of a proposed regulation on social capital could be assembled on a similar scale. A draft regulation usually covers more than one issue. Each one of them would be listed and assessed separately. A questionnaire elaborated on this idea could be used by independent experts to assess the impact of the draft's provisions on social capital at the local, regional and national levels. Summarizing table would collect the results and allow identifying the most likely impact of the proposed provisions on social capital.

Table 2 serves as illustration of the approach and the procedure in some selected areas and possible impact assessments.

${ }^{25}$ Cf. the discussion on the crimes number drop in the United States (Levitt, Dubner, 2006, p. 117). 
Table 2: Eventual impact of particular legal changes on social capital

\begin{tabular}{|c|c|c|c|}
\hline & \multicolumn{3}{|c|}{ Levels of impact } \\
\hline Types of changes & $\begin{array}{c}\text { Small } \\
\text { communities }\end{array}$ & Regions & Country \\
\hline $\begin{array}{c}\text { Relaxing rules for acquiring } \\
\text { citizenship }\end{array}$ & $\mathrm{B}$ & $\mathrm{BB}$ & $\mathrm{A}$ \\
\hline $\begin{array}{c}\text { Strengthening territorial } \\
\text { integration }\end{array}$ & $\mathrm{A}$ & $\mathrm{A}$ & $\mathrm{A}$ \\
\hline $\begin{array}{c}\text { Strengthening the autonomy } \\
\text { of national or ethnic groups }\end{array}$ & $\mathrm{AA}$ & $\mathrm{A}$ & $\mathrm{B}$ \\
\hline $\begin{array}{c}\text { Expanding autonomy of local } \\
\text { self-government }\end{array}$ & $\mathrm{AA}$ & $\mathrm{AA}$ & $\mathrm{AA}$ \\
\hline $\begin{array}{c}\text { Expanding autonomy of } \\
\text { professional associations }\end{array}$ & $\mathrm{AA}$ & $\mathrm{A}$ & $\mathrm{B}$ \\
\hline $\begin{array}{c}\text { Facilitation of economic } \\
\text { activities }\end{array}$ & $\mathrm{AA}$ & $\mathrm{AA}$ & $\mathrm{AA}$ \\
\hline $\begin{array}{c}\text { Expanding contractual } \\
\text { freedom }\end{array}$ & $\mathrm{B}$ & $\mathrm{A}$ & $\mathrm{A}$ \\
\hline
\end{tabular}

Source: Authors

The grades above may change somewhat depending on whether the level of small communities, regions or the whole country is considered. For instance, increasing autonomy of national or ethnic groups affects social capital at the local and regional levels positively. However, at the country level it can lead to conflicts between groups, and as a result - to deteriorate the stock of social capital (cases of Spain or Belgium show the likelihood of such a scenario).

\section{CONCLUSION}

Poland offers an interesting case for studying the evolution or social capital and its vicissitudes. Over the last 100 years, both integrating and disintegrating tendencies could be observed. Those tendencies stemmed from the overall political and economic conditions of the country and from the way, the government attempted to deal with the problems.

Variety of social and political as well as ethnic's interests in the early 20 years of independence (after 1918) required binding material to create a society sharing the same goals. Certain economic successes, slowed 
down by the crisis of the 30s, were not sufficient to build social capital integrating the society. The hardship of WWII and resistance against the occupying powers contributed to better cooperation within Polish society. The end of WWII and the new country borders contributed to ethnic homogenization. Re-settlement of some minority ethnic groups finally ended armed conflicts, enforced and supervised by the state. Theoretically, it should have encouraged and facilitated cooperation within culturally and ethnically uniform society. In practice however, the government (imposed and protected by the Soviet Union) created a deep divide between its opponents and the beneficiaries of the new system. Soviet- typed socialism made new winners and losers. Oppressive system of power was set in place to pacify the dissatisfied. It was even strengthened by means of propaganda driving a wedge between different social groups. In selected areas priority was given to "industrial workers" or "peasants", who by the way, benefited directly from the land reform. White collars and intellectuals were coming next. Private businesspersons and former large landowners (whose land ownership was limited by the land reform to 50ha only), were at the bottom and considered the classes not to be trustworthy.

The state institutions formally determined the cooperation among social groups. Social initiative of cooperation coming from citizens or informal groups was not welcomed. It had to be integrated into the system of existing state-controlled institutions or be considered hostile to the state and banned. The system, which did not enjoy general support, quickly showed its economic inefficiencies corrected by a number of "reforms" implemented every couple of years. Shortly improvements were, however, insufficient to fill in the growing technological gap between Poland and the market economies. A complete turn-point was necessary. This was just after the fall of the Soviet Union, which coincided with deep economic crisis of Polish economy in 1989. This date marks the beginning of Polish transition.

Poland started this process by introducing democratic government institutions and market mechanisms along with privatization processes of the former state property. The support of the overwhelming majority for the changes was enabled by social capital built on opposition to the ruling party and its government. It also helped the new government, formed in a democratic way, to implement less popular programs. Hasty privatization allowed fortunes on the one hand and left the majority's hopes not satisfied on the other. High rate of unemployment, a result of industrial restructuring, forced the government to offer an extensive program of social spending (unemployment benefits and subsidies of all kinds to poor people). It helped 
to ease the hardship of transition, however, this policy had to be financed by proceeds from privatization and by budget deficits.

Policy of transition completely paid no attention to problems of changes in mentality and problems of social capital. Almost 50 years of socialist economy shaped up a soviet type mentality called "homo sovieticus" (Tyszka, 2009, pp. 507-522; Świda-Ziemba, 1994, pp. 223-239). ${ }^{26}$ People got used to address the state or its representatives to seek for help and assistance to solve their material problems, be it housing, supply of goods, health or children education. "They" (meant the state) were responsible for all the ills and the last resort to cure them. Consequently, people were not used to cooperate in solving their immediate needs at the level of informal groups. Social capital of Solidarity Movement was built on political opposition to the government, and later gradually depreciated by the politicians' quarrels, since the Solidarity took power.

At present (2020), the state of social capital has little changed. For political reasons, the government exploits old sentiments. Populistic policy of money distribution together with the hunt for previous government's officials, who could be blamed for their past mistakes, reminiscences of old Roman "panem et circenses" tactic creates new social divisions and destroys almost 30 years of progress in social capital building at all levels. It is not a good prognostic for the future.

Legal system plays a crucial role in building the social capital. Following the independence of Poland, the priority was to unify the countrywide legal system determined before by the three rulers in their respective parts. Several legal institutions from Austrian, Russian and German legal systems, after ad-hoc adjustments stayed preserved in the Polish law. Consequently, the law could not contribute to social capital building.

After WWII, legal system of Poland (and likewise legal systems of other states of the Soviet bloc) served to preserve and protect hardly socially acceptable political and economic system. It contributed to highlighting the differences between identified groups, each of them enjoying different

\footnotetext{
${ }^{26}$ In the early 1990s, heated discussions in Poland about the Soviet mentality were sparked by the publications of the Catholic priest and professor of philosophy, Józef Tischner, who introduced the very term "homo sovieticus" into Polish journalism (Tischner, 1992). However, Tischner was not original in this regard, as the term was coined earlier by the Russian writer, philosopher and dissident Alexander Zinoviev (1922-2006). (Zinoviev, 1986). Tischner added one particular dimension to Zinoviev's analyses. He emphasized that after the collapse of communism, "homo sovieticus" is a person who is unable to use his or her freedom and who is escaping from freedom (Tishner borrowed the famous phrase from Erich Fromm). On complexity of the category "homo societicus", cf. (Kania, 2012).
} 
privileges. Due to bureaucratic character of this law, it did not help to strengthen the social capital.

The transition required a in- depth- review of the legal system and making it compatible with the EU law. Law making demands time and reflection. The pace of changes did not allow analysing integration of the changes within the system properly. Under those conditions, the new laws required quite often amendments, which concentrated mostly on compliance issues. Social capital building aspects were formally and practically forgotten. Our suggestions on how to deal with social capital in the law-making processes are intended to propose some corrective measures.

\section{REFERENCES}

AJNENKIEL, A. (1962). Wiadomości wstępne. In: RYSZKA, F. (ed.), Historia państwa i prawa Polski (1918-1939), Vol. I. Warszawa: Państwowe Wydawnictwo Naukowe, 1962, pp. 11-49.

BUGGLE, J. C. (2016). Law and social capital: Evidence from the Code Napoleon in Germany. In: European Economic Review. Vol. 87, 2016, pp. 148-175.

DAHRENDORF, R. (1959). Class and Class Conflict in Industrial Society. Stanford: Stanford University Press, 1959.

DAHRENDORF, R. (2017). Reflections on the Revolution in Europe. Abington and New York: Routledge, 2017.

DAWIDOWICZ, W. (1959). Zagadnienia prawne melioracji wodnych $w$ rolnictwie. Warszawa: Państwowe Wydawnictwo Naukowe, 1959.

EISLER, J. (2005). Myths and Stereotypes in Poland under the Communist Rule. In: Acta Poloniae Historica. Vol. 91, 2005, pp. 153-183.

FRIEDMAN, M. (1982). The Role of Government in a Free Society. In: FRIEDMAN, M. Capitalism and Freedom. Chicago: University of Chicago Press, 1982, pp. 22-36.

French Civil Code. (1804). [online]. Available at: http://www.napoleonseries.org/research/government/code/book1/c_title05.html\#chapter6 [Accessed October 15, 2018].

GŁÓWNY URZĄD STATYSTYCZNY. (2018). Sytuacja demograficzna Polski do 2017 r. Urodzenia i dzietność. Demographic situation in Poland up to 2017. Births and fertility. Warsaw: Główny Urząd Statystyczny/ Statistics Poland, 2018. [online]. Available at: https://stat.gov.pl/files/ gfx/portalinformacyjny/pl/defaultaktualnosci/5468/33/1/1/sytuacja_ demograficzna_polski_do_2017_r.pdf [Accessed January 30, 2020]. 
GOŁOS, P. (2008). Wspólnoty gruntowe - tradycyjna forma gospodarowania lasami. In: Sylwan. No. 2, 2008, pp. 54-68

KACZMARCZYK, P. (ed.). (2008). Współczesne migracje zagraniczne Polaków. Aspekty lokalne i regionalne. Warszawa: Ośrodek Badań nad Migracjami Uniwersytetu Warszawskiego, 2008.

KANIA, E. (2012). Homo sovieticus - „jednowymiarowy klient komunizmu”, czy „fenomen o wielu twarzach”? In: Przegląd Politologiczny. № 3, 2012, pp. 157-170.

KARSKI, J. (2013). Story of a Secret State: My Report to the World. Georgetown: Georgetown University Press, 2013.

KERSTEN, K. (1991). The Establishment of Communist Rule in Poland, 19431948. Berkeley - Los Angeles - Oxford: University of California Press, 1991.

KHAN, F.A., ALAM, A. ANÓS CASERO, P. (2008). Unleashing Prosperity. Productivity Growth in Eastern Europe and the Former Soviet Union. Washington DC: The World Bank, 2008.

KNACK, S. (2003). Social capital, growth, and poverty: a survey. In: GROOTAERT, C. BASTELAER T. VAN, (ed.). The Role of Social Capital in Development: An Empirical Assessment. Cambridge: Cambridge University Press, 2003, pp. 42-84.

KORALEWICZ, J., BIAŁECKI, I., WATSON, M., (ed.). (1987). Crisis and Transition: Polish Society in the 1980s, Oxford, New York, and Hamburg: Berg, 1987.

KORYŚ, P. (2018). Poland from Partitions to EU Accession. A Modern Economic History, 1772-2004. Cham, Switzerland: Pelgrave - Macmillan, 2018.

KORZYCKA, M. (2018). Z problematyki relacji prawa zwyczajowego do stanowionego $\mathrm{w}$ polskim prawie rolnym. In: ŁOBOS-KOTOWSKA, D., GAŁA, P., STAŃKO, M. (ed.). Współczesne problemy prawa rolnego i cywilnego. Ksiega jubileuszowa Profesor Teresy Kurowskiej. Warszawa: Fundacja FAPA, 2018, pp. 183-194.

KOWALIK, T. (2011). From Solidarity to Sellout. The Restoration of Capitalism in Poland. New York: Monthly Review Press, 2011.

LANDAU-CZAJKA, A. (2006). Syn będzie Lech... Asymilacja Żydów w Polsce międzywojennej. Warszawa: Wydawnictwo Neriton, 2006.

LEVELS, M., SCHEEPERS, P., HUIJTS, T., KRAAYKAMP, G. (2015). Formal and Informal Social Capital in Germany: The Role of Institutions and Ethnic Diversity. In: European Sociological Review. Vol. 31, No. 6, 2015, pp. 766779. 
LEVITT, S. D., DUBNER, S. J. (2006). Freakonomics. London: Penguin Books, 2006.

ŁASKI, K., BHADURI, A. (1997). Lessons to be drawn from main mistakes in the transition strategy. In: ZECCHINI S. (ed.). Lessons from the Economic Transition. Central and Eastern Europe in the 1990s. Dordrecht and Boston: Kluwer Academic Publishers, 1997, pp. 103-121.

MAGDA, I., KIEŁCZEWSKA, A., BRANDT, N. (2018). The 'Family 500+' child allowance and female labour supply in Poland. In: IBS Working Paper. No. 1, 2018, pp. 4-18.

MEAD, L. M. (1986). Beyond Entitlement: The Social Obligations of Citizenship. New York and London: The Free Press - Collier Macmillan Publishers, 1986.

NOWAKOWSKI, M. (2006). Historyczny rozwój spółki wodnej na ziemiach polskich. In: Roczniki Nauk Prawnych. Vol. 16, No. 2, 2006, pp. 449-468.

OSTROM, E. (1990). Governing the commons. The evolution of institutions for collective action. Cambridge: Cambridge University Press, 1990.

PICKETTY, T. (2014). Capital in the Twenty-First Century. London: The Belknap Press of Harvard University Press, 2014.

PRAŻMOWSKA, A. J. (2002). The Kielce Pogrom 1946 and the Emergence of Communist Power in Poland. In: Cold War History. Vol. 2, No. 2, 2002, pp.101-124.

PUTNAM, R. D. (2000). Bowling Alone. The Collapse and Revival of American Community. New York: Simon \& Schuster, 2000.

PUTNAM, R. D., LEONARDI, R., NANETTI, R. Y. (1993). Making Democracy Work. Civic Traditions in Modern Italy. Princeton: Princeton University Press, 1993.

RAISER, M. (2001). Informal Institutions, Social Capital, and Economic Transition: Reflections on a Neglected Dimension. In: CORNIA, G. A., POPOV, A. (ed.). Transition and Institutions: The Experience of Gradual and Late Reformers. Oxford: Oxford University Press, 2001, pp. 218-239.

ROGOWSKI, W., SZPRINGER, W. (2007). Problemy metodologiczne oceny skutków regulacji w Polsce - czy powstają nowe perspektywy ekonomicznej analizy prawa? In: ROGOWSKI, W., SZPRINGER, W. (ed.). Ocena Skutków Regulacji - poradnik OSR, doświadczenia, perspektywy. Warszawa: C.H. Beck, 2007, pp. 3-18.

RUZIK-SIERDZIŃSKA, A. (2018). Krótkookresowe skutki programu Rodzina 500+. In: Studia z Polityki Społecznej. Vol. 17, No.1, 2018, pp. 63-75.

SACHS, J. (1994). Shock Therapy in Poland: Perspectives of Five Years. In: The Tanner Lectures on Human Values. [online]. Available at: https:// 
tannerlectures.utah.edu/_documents/a-to-z/s/sachs95.pdf [Accessed January 30, 2020].

SEN, A. (2009). The Idea of Justice. Cambridge, Mass.: Belknap Press, 2009. STIGLITZ, J. E. (2012). The Price of Inequality. New York and London: W.W.Norton \& Company, 2012.

STRZELCZYK, R., TURLEJ, A. (2015). Własność lokali. Komentarz. Warszawa: C.H. Beck, 2015.

SZCZEPAŃSKA, M. (2014). Wspólnota mieszkaniowa jako przedmiot zainteresowania socjologii. In: Przegląd Socjologiczny. Vol. 63, No. 1, 2014, pp. 197-216.

ŚLIWA, R., ŻABA-NIERODA, R. (2017). Ocena skutków regulacji jako element procesu regulacyjnego. In: Rocznik Administracji Publicznej. No. 3, 2017, pp. 364-379.

ŚWIDA-ZIEMBA, H. (1994). The Post-Communist Mentality. In: JAWŁOWSKA, A., KEMPNY, M. (ed.). Cultural dilemmas of post-communist societies. Warsaw: IFiS Publishers, 1994, pp. 223-239.

SZTOMPKA, P. (2007). Zaufanie: fundament społeczeństwa. Kraków: Wydawnictwo Znak, 2007.

SZTOMPKA, P. (2016). Kapitał społeczny. Teoria przestrzeni międzyludzkiej. Kraków: Wydawnictwo Znak, 2016.

TIDEMAN, S. G. (2011). Gross National Happiness. In: ZSOLNAI, L. (ed.). Ethical Principles and Economic Transformation - A Buddhist Approach. Dordrecht: Springer, 2011, pp. 133-153.

TIDEMAN, S. G. (2016). Gross National Happiness: lessons for sustainability leadership. In: South Asian Journal of Global Business Research. Vol. 5, No. 2, 2016, pp. 190-213.

TISCHNER, J. (1992). Etyka solidarności i Homo sovieticus. Kraków: Społeczny Instytut Wydawniczy Znak, 1992.

TITTENBRUN, J. (2013). Ralph Dahrendorf's Conflict Theory of Social Differentiation and Elite Theory. In: Innovative Issues and Approaches in Social Sciences, Vol. 6, No. 3, 2013, pp. 117-140.

TRACZ, B. (2015). Mięso spod lady, warzywa z działki, kawa z zagranicznej paczki. Strategie przetrwania mieszkańców aglomeracji górnośląskich w warunkach kryzysu. In: JARSKA, N., OLASZEK J. (ed.). Społeczeństwo polskie w latach 1980-1989. Warszawa: Instytut Pamięci Narodowej, 2015, pp. 37-53.

TREMBICKA, K. (2014). Kategoria wroga w komunistycznej Polsce w latach 1956-1989. In: Annales Universitatis Mariae Curie-Skłodowska, Lublin Polonia. Sectio K. Vol. XXI, No. 2, 2014, pp. 105-120. 
TYSZKA, K. (2009). Homo Sovieticus Two Decades Later. In: Polish Sociological Review. No. 4, 2009, pp. 507-522.

WOOLCOCK, M. M. (2001). The place of social capital in understanding social and economic outcomes. In: Isuma: Canadian Journal of Policy Research. Vol. 2, No. 1, 2001, pp. 11-17.

ZAREMBA,M.(2005).Komunizm,legitymizacja,nacjonalizm.Nacjonalistyczna legitymizacja władzy komunistycznej w Polsce. Warszawa: Wydawnictwo Trio, 2005.

ZINOVIEV, A. (1986). Homo Sovieticus. London: Paladin Grafton Books, 1986. ZUBEK, R. (2007). Jak i dlaczego reformować ocenę skutków regulacji w Polsce? Opracowanie przygotowane na zlecenie Rzecznika Praw Obywatelskich (wersja ostateczna 26/01/2007). [online]. Available at: https://www.rpo.gov.pl/pliki/12180262910.pdf [Accessed April 9, 2019].

ZULETA FERRARI, M. (2012). Social Capital, Trust and Legal Institutions. PhD Thesis. Milan: University of Milan. [online]. Available at: https://air. unimi.it/retrieve/handle/2434/215991/264251/phd_unimi_R07540. Pdf [Accessed October 14, 2018].

ZULETA FERRARI, M. (2016). Trust in Legal Institutions: an Empirical Approach from a Social Capital Perspective. In: Oñati Socio-legal Series. Vol. 6, No. 5, 2016, pp. 1141-1170. 